\title{
Comparative Evaluation of Agronomic Performance of Selected Landraces And Improved Groundnuts Cultivars In Central Uganda
}

John W Mulumba ( $\sim$ jwmulumba@yahoo.com )

National Agricultural Research Organisation

Ronald Kakeeto

National Semi arid Resources Research Institute

Rose Nankya

Alliance of Bioversity International and CIAT: Alliance of Bioversity International and International Center for Tropical Agriculture

Hannington Lwandasa

National Agricultural Research Laboratories-Kawanda

Brian Isabirye

Kawanda Agribusiness Consult

Devra Jarvis

Alliance of Bioversity International and CIAT: Alliance of Bioversity International and International Center for Tropical Agriculture

\section{Research Article}

Keywords: Diversity, peanuts, conservation, germplasm

Posted Date: July 30th, 2021

DOl: https://doi.org/10.21203/rs.3.rs-696706/v1

License: (9) (1) This work is licensed under a Creative Commons Attribution 4.0 International License. Read Full License 


\section{Abstract}

Groundnut (Arachis hypogaea L.) is important for providing food, income, livestock fodder for smallholder farmers, and improving soil fertility. However, groundnut yields on farmers' fields in SubSaharan Africa are still very low due to various constraints. Several groundnut cultivars are available within the farmer's domain but the adoption of these varieties favours landraces as opposed to improved varieties. Limited information is available on performance of commonly grown cultivars for guiding selection by different user groups (farmers, breeders and other users). This study was thus designed to determine the performance of selected landraces and improved groundnut varieties in Uganda. 23 groundnut lines with varying degrees of tolerance to a range of stresses were evaluated at two sites. Results showed significant $(P \leq 0.05$ to $P \leq 0.001)$ differences among genotypes for yield. Significant $(P \leq 0.05$ to $P \leq 0.001)$ varietal differences were also observed between landraces and improved varieties for growth and physiological traits but not for pest and disease reaction. Clustering was not evident on the basis of either landraces or improved cultivars for pests and diseases incidences. However, associations of a mix of both groundnut classes of with particular diseases and/or pests were observed. Varieties such as India, Serenut 10, Kabonge, and DOK Tan associated with diseases such as rosette virus disease and its vector pest, the aphids. The results reported in this study shall be useful for driving the development of new cultivars owing to their good adaptability and acceptance thus the need to conserve and ensure sustainable use of these germplasm.

\section{Introduction}

Groundnut (Arachis hypogaea L.) is an economically valuable oilseed and cash crop grown extensively in the semi-arid tropical regions of the world. It is cultivated for direct consumption as food and for industrial use. Production of the crop is concentrated primarily in the semi-arid tropical regions of Asia and Africa, which together account for over $96 \%$ of world groundnut area and $92 \%$ of total global groundnut output. In Uganda, groundnut is the second most important legume after common bean (Okello et al. 2010; 2014). Besides being a major food crop, it also represents a significant source of income, thus contributing to improved livelihoods. Groundnut seeds contain 40-50\% high quality edible oil, $20-50 \%$ easily digestible protein and $10-20 \%$ carbohydrate depending on variety. Groundnut is also a nutritional source of vitamin E, niacin, falacin, calcium, phosphorous, magnesium, zinc, iron, riboflavin, thiamine and potassium (Savage and Keenan 1994). This makes groundnut an important source of nutrition in the country. In Uganda, groundnut is grown in diverse environments; and also utilized in various ways leading to diversity in variety preferences for this crop.

Most literature on seed supply systems for crop varieties often refers to seeds as either 'modern varieties' or 'landraces'. While a 'modern variety' is understood to be a variety that is improved by a formal breeding programme (Morris et al. 2003), released under a registered name and differing from other varieties by distinctive properties for which it is uniform and breeds true, a "landrace" is defined as dynamic population of a cultivated plant with a historical origin, distinct identity, often genetically diverse and locally adapted, and associated with a set of farmers' practices of seed selection and field management 
as well as with a farmers' knowledge base (Villa et al. 2005). The main contributions of landraces to plant breeding have been traits for adaptation to stressful environments such as water stress, salinity, low-input farming system, high temperatures and several biotic stresses such as pests and diseases ( Zeven 1998; Paterniani et al. 2000; Sharma et al. 2000; Araújo et al. 2002; Kashiwagi et al. 2005; Herzberg et al. 2004; Futakuchi et al. 2003) as well as useful genes for nutrient dense foods. As such, they act as useful starting materials for variety development strategies carried out at present and also for future use. In addition, a more efficient use of plant genetic diversity has been identified as a prerequisite for meeting the challenges of development, food security and poverty alleviation (FAO 1996). Therefore, it is of great importance to conserve and maintain a broad base of germplasm because they constitute valuable genetic resources for multiple desirable traits within the country's groundnut gene pool.

In Uganda, groundnut production is characterized by resource-constrained small-scale farmers who cannot afford inputs such as improved seed and fertilisers and, therefore rely on fellow farmers, farmer groups, local markets, NGOs and research organisations for these inputs (Mugisha et al. 2014). Given the lack of capital resources, the farmers are left with no option but to resort to using traditional farming methods with low levels of mechanisation, and many a time with varieties which compromise yields of the crop despite the existence of a wide range of varietal choice ranging from well adapted, but not readily available traditional varieties (due to lack of entry point into the formal seed system) to a number of released varieties which have been improved for several traits.

Several pests and diseases attack groundnuts leading to reduction of yields and lowering the quality of produce hence increasing the cost of production. The major diseases of groundnuts include: Rosette caused by a complex of three viruses namely; Groundnut Rosette Virus (GRV), Groundnut Rosette Assistor Virus (GRAV) and satellite RNA (satRNA) transmitted by a single species of aphid (Aphis craccivora Koch); Early Leaf Spot (Cercospora arachidicola); Late Leaf Spot (Phaeoisariopis personata); Root Rot; Mosaic; Rust (Puccinia arachids) and aflatoxin contamination (caused by Aspergillus niger and Aspergillus flavus). The Groundnut Rosette Virus Disease (GRVD) is considered the most important constraint and can cause losses of up 100\% if it occurs before flowering (Okello et al. 2010; Nigam et al. 2012).

The important pests of groundnut are aphids (Aphis craccivora Koch), a vector of groundnut rosette disease, leaf miner (Aproarema modicella Deventer), thrips (Thrips palmi Karny, Frankiniella schultzie Trybom, Scirtothrips dorsalis Hood) and termites (Isoptera) (Okello et al. 2010; Okello et al. 2014). Thrips and aphids are considered more important as vectors of viruses than as causing direct damage to groundnuts. In addition, the Groundnut Leaf Miner, a Lepidopteran defoliator was reported as an emerging threat to groundnut production areas in Uganda, especially those areas prone to drought (Mukankusi et al. 2000; Okello et al. 2010).

As groundnut is grown in predominantly semi-arid regions characterized by erratic rainfall and on predominantly loose sandy loam soils, drought is often a recurring production constraint. This situation also coincides with the climate change phenomenon which projects disturbances such as a decrease in 
the lengths of the rainy seasons especially in semi-arid tropics (SAT) where most groundnuts are grown (Pasupuleti and Nigam 2013). In addition, drought has significant implications on groundnut quality which undermines the value of groundnut products on local, regional and international markets.

The foregoing constraints notwithstanding, the success of a plant breeding program is anchored upon its ability to provide farmers with genotypes with guaranteed superior performance (phenotype) in terms of yield and/or quality across a range of environmental conditions. To achieve this aim, it is necessary to have an understanding of the factors leading to a good phenotype. Generally, the phenotype is the value for a trait at the end of the growing season, e. g kernel weight at maturity, and is the cumulative result of a number of continuous interactions between the genetic make-up of the plant (the genotype) and the conditions or stimuli in which that plant developed (the environment) and this varies from plant to plant.

Environments differ in the amount and quality of inputs and stimuli that they convey to plants including, e.g., the amount of water, nutrients or incoming radiation. The primary objective in plant breeding is to match genotypes and environments in such a way that improved phenotypes are obtained. As quantitatively inherited trait, seed yield performance of a genotype often varies from one environment to another, leading to a significant genotype by environment (GxE) interaction which can severely limit gain of selecting superior genotypes. Understanding the interaction of those factors and how they affect seed yield is crucial for maintaining high yield (David et al. 2016). It is acknowledged that there can be genotypes that do well across a wide range of conditions (widely adapted genotypes), but there are also genotypes that do relatively better than others exclusively under a restricted set of conditions (specifically adapted genotypes). Specific adaptation of genotypes is closely related to the phenomenon of genotypeby environment interaction (GEI). GEI exists whenever the relative phenotypic performance of genotypes depends on the environment, or in other words, when the difference in reactions of genotypes varies with the environment. Some scenarios that can occur when comparing the performances of pairs of genotypes across environments are presented in Fig. 1. The function describing the phenotypic performance of a genotype in relation to an environmental characterization is called the "norm of reaction" (Griffithsetal.1996). Figure 1A shows the case where there is no GEl, the genotype and the environment behave additively and the reaction norms are parallel. The remaining plots show different situations in which GEl occurs: divergence (Fig. 1B), convergence (Fig. 1C), and the most critical one, cross over interaction (Fig. 1D). Cross over interactions are the most important for breeders as they imply that the choice of the best genotype is determined by the environment.

Therefore, given the complexity of the mechanisms and processes underlying the phenotypic response across diverse and changing environmental conditions, several analytical tools have been developed to help breeders understand GEI (Yates and Cochran 1938; Finlay and Wil- kinson 1963; Eberhart and Russell 1966; Gauch 1988; Singh et al. 1996b) among others. The use of adequate strategies to analyze GEl is a first and important step toward more informed breeding decisions but details of how these tools are used is beyond the scope of this study. However, in finding workable solutions to limited information on performance of commonly grown groundnut landraces and improved varieties for guiding selection of groundnut varieties by different user groups (farmers, breeders and other users), the specific objectives of 
this study therefore were; (i) to interpret genotype (G), Class (Landrace and improved varieties) and Site (E) main effects and GE interaction for growth, pests and disease reaction, and yield performances of 23 groundnut genotypes evaluated in two growing sites (ii) Explore the nature of GE interaction and suggest strategies for exploiting it for improved targeting of varieties to different growing sites.

\section{Materials And Methods}

\section{Site description}

The study was carried out in the Central Wooded Savanna ecological zone of Uganda, in Nakaseke $\left(0^{\circ} 43^{\prime} 29^{\prime \prime} \mathrm{N}, 32^{\circ} 54^{\prime} 04^{\prime \prime} \mathrm{E}\right)$ and Nakasongola ( $\left.1^{\circ} 18^{\prime} 32^{\prime \prime} \mathrm{N}, 32^{\circ} 27^{\prime} 23^{\prime \prime} \mathrm{E}\right)$ districts. In Nakasongola, the annual daily temperatures range from $18^{\circ} \mathrm{C}$ to $35^{\circ} \mathrm{C}$, with mean daily maximum of $30^{\circ} \mathrm{C}$. Rainfall ranges between 500 to $1000 \mathrm{~mm}$ per annum and there are two rain seasons. The vegetation in the study site mainly comprises three vegetation cover types depending on the extent of anthropogenic activities/disturbance on specific ranch sites. The three vegetation cover types include dense vegetation cover ( $>50 \%$ basal cover), sparse vegetation cover ( 25 to $50 \%$ basal cover) and bare ground. The area is characterized by prolonged droughts and floods due to shifting rainfall pattern (Nimusiima et al. 2013). Hitherto dominated by livestock grazing, the area is increasingly changing in land use, with crop farming especially for maize production becoming common. The altitudinal range is $600-1160 \mathrm{msl}$.

Nakaseke site has traditionally been described as the coffee-banana farming system. This area falls within an altitudinal range of 1086-1280 masl, with mean annual rainfall of up to $1100 \mathrm{~mm}$. The annual daily temperatures range from $16 \circ \mathrm{C}$ to $30 \circ \mathrm{C}$.

Bi-modal rainfall distribution characterizes the two districts with the first rainy season extending from March to June, while the second rainy season starts in late August or early September to NovemberDecember (Ogwang et al.2016). The main rain season occurs from March-April to June July while the second rain season follows from August to October November. A long dry season occurs from December to February while a short spell comes around July-August.

Trial gardens were established in two districts of Nakasongola and Nakaseke, each district taken as a site. In each site replication was done in four villages. In Nakaseke trial gardens were established in the villages of Kiziba, Namirali, Kalagala and Kyamutakasa while in Nakasongola they were established in Naitondo, Kasambya, Kalobokwe and Kiralamba (Figure 1 \& Figure 2)

\section{Field layout}

Twenty-three groundnut varieties were planted in each site. The varieties included improved and farmer local varieties. The seeds for the improved varieties were sourced from the National Agricultural Semi-Arid Resources Research institute (NASARRI) while the farmer local varieties were from farmers in Amuria district. Each variety was planted to a single plot of $3 \mathrm{~m} \times 4 \mathrm{~m}$ and at a plot-plot spacing of $1 \mathrm{~m}$ with a 
plant population of 300 plants. A row to row spacing of $40 \mathrm{~cm}$, and plant to plant spacing of $10 \mathrm{~cm}$ was used.

\section{Data collection}

Data was taken on common groundnut diseases and pests. The diseases included; Groundnut Rosette, Leaf Spot, Root-rot, and Groundnut Mosaic while the pests included aphids and leaf minor. Disease and pest incidences were assessed (at 1,2 and 3 months after planting by counting the number of plants affected per variety (NaSARRI, unpublished). In addition, plant growth performance was assessed by measuring plant height while germination uniformity was scored 2 weeks from germination (Wood and Roper, 2000). Using a scale of 1 to 4 , where $1=$ poor and $4=$ very good performance. Stay green as a measure of drought tolerance was also evaluated using a scale of 1 to 4 which were subsequently converted to percentages. Yield was assessed in terms of number of pods per plant measured on twenty selected plants from five middle rows per plot for each variety

\section{Disease scores}

\section{Leaf spot (Early and late leaf spot disease)}

Each leaf spot disease was scored separately using 1-9 scale on periodic basis after first appearance of the disease and subsequent scoring was done at an interval of 15 days and stopped at 20 days before harvest. Leaf spot was recorded using 9-point scale as described below (Subrahmanyam, P. et al. 1995). The severity scores were used to compute the area under disease progress curve AUDPC values (Van Der Plank 1965).

\section{Groundnut Rosette Virus Disease (GRVD) severity rating}

Visual assessments and scoring of GRVD severity were carried out thrice; at 30, 60 and 90 days after planting (DAP). The disease severity on each individual plant was rated using a quantitative scale adapted from Waliyar et al. (2007) as follows: no visible symptoms on leaf (highly resistant), rosette symptoms covering 1 - $20 \%$ of leaf area but no obvious stunting (resistant), rosette symptoms on $21-50 \%$ area of leaf with stunting (moderately resistant), severe rosette symptoms on $51-70 \%$ area of leaf with stunting (susceptible), and severe symptoms on $71-100 \%$ area of leaf with stunting (highly susceptible). Area under the disease progress curve (AUDPC) values were calculated.

\section{Root rot}

This disease was scored after first appearance of plants showing rot root symptoms and subsequent scoring was done at an interval of 15 days up to 30 days after planting. Scoring was done based on visual rating scale of 0 to 3 where: $0=$ clean, $1=$ slight, $2=$ moderate and $3=$ severe (Ledingham et al. 1973). Area under the disease progress curve (AUDPC) values were calculated.

\section{Groundnut Mosaic (CABMV)}


Disease severity was scored using a scale of 1-5 (Adamu et al.2015) as follows: 1 = no symptoms (apparently healthy plant); 2 = mild mosaic (10-30 \% infection); 3 = moderate mosaic (31-50 \% infection); 4 = severe mosaic, chlorosis and stunting; (51-70 \% infection); 5 = very severe mosaic, chlorosis, stunting; and plant dead (>70 \% infection). Area under the disease progress curve (AUDPC) values were calculated.

\section{Leaf miner and aphids}

Observations on leaf miner incidence and defoliator damage were recorded regularly at 15-days interval. Observations were made on top five leaves of five randomly selected plants in each replication for number of leaflets damaged by leaf miner and extent of defoliation by defoliators. From these observations, per cent incidence of leaf miner and per cent defoliation were calculated.

\section{Agronomic data}

Data on selected agronomic traits were collected on plot basis. Yield data were recorded from five middle rows, excluding plants at the end of rows for each of the variety, based on number of pods per plot. All plants were clipped at the soil surface, the pods were dug up and pods were then detached, bulked together and counted.

\section{Stay green trait}

Starting from pod initiation to physiological maturity, visual scoring for stay-green were carried out at two-weeks intervals. The stay-green characteristic of the genotypes was scored on a scale of 1 to 5 based on the proportion of the total leaf area that had senesced with 1 being no leaf senescence and 5 completely senesced plant (Xu et. 2000). The stay green scores were used to compute the leaf area under greenness (LAUG) values (Joshi et al. 2017).

\section{Data analysis}

Data for each variety was summarised using descriptive statistics with means presented with respective standard error of the means. All variables were tested for normality using Shapiro-Wilk test and the strongly skewed variables were transformed prior to analyses of variance where necessary, to meet the assumption of normality and homogeneity of variances. Variables expressed as percentages (\%) were arcsine-square-root $(+0.5)$ transformed, while counts of individuals were $\log (\log (x+1))$ transformed. Where transformation was not sufficient to improve data shape, an appropriate non-parametric test was applied. The differences among varieties in yield performance was compared using analysis of variance (ANOVA), with post-hoc means separation tested using Tukey (HSD) at $5 \%$ probability level. Differences in medians of germination rate (\%), growth (\%), pest and disease incidence, and drought tolerance among varieties were compared using Kruskal-Wallis test, with Mann-Whitney post-hoc medians separation at $5 \%$ probability level. Site and variety interactions in growth performance, pest, and disease and drought tolerance were tested with General Linear Model (GLM) two-way analysis of variance (ANOVA). Where the GLM test indicated significant differences, post-hoc Tukey (HSD) test was used. To assess similarity among varieties, hierarchical cluster analysis using Bray-Curtis distance measure was used to depict 
variety performance similarity with dendrogram. Correspondence analysis ordination with symmetric scaling was used to assess associations between pest and diseases, and the various varieties. All the tests were done using PAST software (Oyvind 2002).

\section{Results}

\section{Evaluation of the groundnut cultivars for yield performance}

The results of the evaluation of the genotypic variation among the groundnut genotypes are presented in Table 1. The one-way ANOVA showed large and significant $(P \leq 0.05$ to $P \leq 0.001)$ mean squares (MS) for differences between groundnut lines for yield performance. The yield of these varieties per se varied from 1,575,284 (Muddugavu) to 4545201(Erudu Red) pods per hectare, with an average yield of $2,551,235$ pods/hectare, regardless of the class of groundnut variety evaluated.

The combined analysis for varieties tested over two growing sites for yield showed non-significant $(\mathrm{P}>$ 0.05) MS for variation between classes of groundnuts (i.e., between the landraces and improved varieties (Table 2 and Table 4). Moreover, the yield of these varieties varied from 1,940,111 (DOK Red) to 3,143,422 (Serenut $12 \mathrm{R}$ ) and from 1,575,284 (Muddugavu) to 4,545,201 (Erudu Red) pods per hectare, with an average yield of 2,494,851 and 2,612,317 pods/hectare for improved and landraces, respectively. 
Table 1

Yield performance of the 25 groundnut cultivars

\begin{tabular}{|c|c|c|c|c|c|}
\hline Accession & Trait & & Accession & Trait & \\
\hline Improved varieties & Yield & & Landraces & Yield & \\
\hline & $(000,000)$ pods & & & $\begin{array}{l}(000,000) \\
\text { pods }\end{array}$ & \\
\hline Serenut 12Red & 1.91 & a & Mudugavu & 1.58 & a \\
\hline DOK Red & 1.94 & a & EruduWhite & 1.69 & $a b$ \\
\hline Serenut 8 Red & 2 & a & Kabonge Red & 1.97 & $a b c$ \\
\hline Serenut 5 Red & 2.21 & $a b$ & Emoit & 2.34 & bcd \\
\hline Serenut 7 Tan & 2.3 & $a b$ & Otira & 2.56 & $\mathrm{~cd}$ \\
\hline DOK Tan & 2.35 & $a b c$ & India & 2.59 & $\mathrm{~cd}$ \\
\hline Serenut 8 Tan & 2.35 & $a b c$ & Kabonge White & 2.6 & $\mathrm{~cd}$ \\
\hline Serenut 11 Tan & 2.38 & $a b c$ & Ogwara & 2.71 & $d$ \\
\hline Serenut 9Tan & 2.42 & $a b c$ & Egoromoit & 2.85 & $d$ \\
\hline Serenut 6 Tan & 2.42 & $a b c$ & Gabon & 2.95 & $d$ \\
\hline Serenut 10 Red & 2.82 & $\mathrm{bc}$ & Kawanda Bulk & 2.95 & $d$ \\
\hline Serenut 14 Red & 2.95 & c & Erudu Red & 4.55 & e \\
\hline Serenut 12 Tan & 3.14 & bc & & & \\
\hline Mean & 2.39 & & & 2.58 & \\
\hline S.E & 0.04 & & & 0.05 & \\
\hline CV(\%) & 67.70 & & & 73.39 & \\
\hline
\end{tabular}

Table 2

Tests for equal means (landraces versus improved groundnut varieties

\begin{tabular}{|llll|}
\hline t value: & $\mathbf{3 . 0 8 5 5}$ & & \\
\hline Critical t value $(\mathrm{P}=0.05):$ & 1.9607 & $\mathrm{p}$ (same mean): & 0.002048 \\
\hline UnEq. Var. t: & 3.0913 & $\mathrm{p}$ (same mean): & 0.00201 \\
Monte Carlo permutation: & & $\mathrm{p}$ (same mean): & 0.0025 \\
\hline
\end{tabular}

Evaluation of the selected groundnut varieties for growth performance 
The results of varietal comparisons based on growth parameters are presented in Table 3. Significant variability $(P \leq 0.05$ to $P \leq 0.001)$ of Kruskal-Wallis $H$-values for varietal trait scores between landraces and the improved was observed for all traits evaluated. The stay green index (drought tolerance) of these varieties varied from 25.1 (Serenut $8 \mathrm{~T}$ and Serenut 12T) to 65 (Serenut $12 \mathrm{R}$ ) and from 25.1 (Erudu white) to 61.25 (Kabonge white), with an average of 45.36 and 48.9 for improved and landraces, respectively. Growth measured as germination percentage of these varieties varied from 50 (Serenut 8T and Serenut $12 \mathrm{~T}$ ) to 79.17 (Serenut $5 \mathrm{R}$ ) and from 33.3 (Erudu red) to 85.25 (Kabonge white), with an average of 66.17 and 67.85 for improved and landraces, respectively. 
Table 3

Comparison of growth performance of Landraces and improved varieties of groundnut

\section{Varieties}

\section{Drought tolerance}

(\% based on greenness)
Traits

Plant height

(cm)

\section{Modern Varieties}

\begin{tabular}{llll|} 
Serenut 14 & $45 \pm 1.9$ & $39.38 \pm 1.4$ & $63.75 \pm 1.4$ \\
\hline Serenut 8 Red & $39.90 \pm 1.7$ & $42.42 \pm 2.3$ & $64.65 \pm 1.7$ \\
\hline Serenut 10R & $47.92 \pm 1.7$ & $44.79 \pm 1.5$ & $58.33 \pm 2.0$ \\
\hline Serenut 5R & $51.04 \pm 2.4$ & $52.08 \pm 2.0$ & $79.17 \pm 1.6$ \\
\hline Serenut 11 Tan & $43.75 \pm 1.9$ & $49.11 \pm 2.2$ & $63.39 \pm 1.6$ \\
\hline Serenut 9 Tan & $46.43 \pm 2.1$ & $49.11 \pm 2.5$ & $84.82 \pm 1.0$ \\
\hline Serenut 6 Tan & $43.75 \pm 2.2$ & $40.63 \pm 1.7$ & $68.75 \pm 1.6$ \\
\hline Serenut 7 Tan & $46.43 \pm 2.1$ & $45.54 \pm 2.3$ & $75 \pm 1.6$ \\
\hline Serenut 12 Red & $65 \pm 2.0$ & $48.75 \pm 1.5$ & $57.5 \pm 1.4$ \\
\hline Serenut 8 Tan & $25 \pm 1.4$ & $25 \pm 0.6$ & $50 \pm 1.1$ \\
\hline Serenut 12 Tan & $25 \pm 1.2$ & $50 \pm 0.3$ & $50 \pm 0.9$ \\
\hline DoK Red & $56.25 \pm 2.6$ & $51.56 \pm 2.0$ & $78.13 \pm 1.6$ \\
\hline DoK Tan & $54.17 \pm 2.8$ & $41.67 \pm 2.2$ & $66.67 \pm 1.7$ \\
\hline Means & 45.36 & 44.62 & 66.17 \\
\hline Landraces & & $41.48 \pm 1.9$ & $67.61 \pm 1.0$ \\
\hline India & $56.25 \pm 3.08$ & $46.43 \pm 2.3$ & $81.25 \pm 0.9$ \\
\hline Otira & $50 \pm 2.33$ & $44.64 \pm 2.1$ & $77.68 \pm 0.9$ \\
\hline Emoit & $47.22 \pm 1.63$ & $39.58 \pm 1.6$ & $73.61 \pm 1.3$ \\
\hline Kabonge Red & $56.25 \pm 2.50$ & $52.08 \pm 2.2$ & $72.92 \pm 1.4$ \\
\hline Egromoit & $45.45 \pm 2.0$ & $59.38 \pm 1.1$ & $41.67 \pm 1.7$ \\
\hline Gabon & $53.57 \pm 2.9$ & $49.46 \pm 1.4$ \\
\hline Muddugavu & $45.54 \pm 2.3$ & & \\
\hline
\end{tabular}

*Means sharing the same letter in the column label are not significantly different at the $5 \%$ level 


\begin{tabular}{|llll|}
\hline Varieties & \multicolumn{3}{l|}{ Traits } \\
\hline Kabonge White & $61.25 \pm 3.2$ & $56.25 \pm 2.9$ & $85.25 \pm 1.5$ \\
\hline Ogwara & $47.22 \pm 2.4$ & $45.14 \pm 2.0$ & $71.53 \pm 1.1$ \\
\hline Kawanda Bulk & $50 \pm 1.8$ & $40.28 \pm 1.2$ & $61.11 \pm 1.3$ \\
\hline Erudu white & $25 \pm 1.6$ & $25 \pm 1.0$ & $68.75 \pm 1.2$ \\
\hline Erudu Red & $50 \pm 1.0$ & $58.33 \pm 0.0$ & $33.33 \pm 0.8$ \\
\hline Means & 48.98 & 46.10 & 67.85 \\
\hline $\begin{array}{l}\text { H (chi Squared } \\
\text { value) }\end{array}$ & 197.1 & 262.1 & 767 \\
\hline Hc (tie corrected) & 235.6 & 308.9 & 903 \\
\hline P (0.05) & $1.151 \mathrm{E}-36$ & $2.715 \mathrm{E}-51$ & $3.442 \mathrm{E}-175$ \\
\hline $\begin{array}{l}\text { U-test (U, P - } \\
\text { Value) }\end{array}$ & $1.21 \mathrm{E}+06,0.0039$ & $1.27 \mathrm{E}+06$, & $1.20 \mathrm{E}+06$, \\
\hline *Means sharing the same letter in the column label are not significantly different at the $5 \%$ level \\
\hline
\end{tabular}

\section{Evaluation of the groundnut cultivars for pest and disease reaction}

The results of U-test for difference in reaction to pests and diseases by improved and landrace groundnuts lines are presented in Fig. 1. Although improved varieties showed better resistance to pests and diseases (Fig. 1), the difference between landrace and improved varieties was not significant $(P>$ 0.05).

Results of association of diseases and pests with test varieties, using correspondence ordination analysis with symmetric scaling explained by principal components accounting for $65 \%$ of total variation among the accessions, showed that the most resistant genotypes to virus diseases by graphical positioning were Gabon, Serenut 5, Serenut 14, Serenut 5, Serenut 12, Ogwara, Otira and Egoromoit (Fig. 2 and Fig. 3). However, all the varieties were tolerant to leafspot diseases owing to the position and separation between varieties and leaf spot diseases. Moreover, varieties such as India, Serenut 8, Serenut 6 , Serenut 10, Kabonge, Mudugavu, DOR red, DOK clustered with diseases (Yellow Mosaic and Green Rosette) and their vector pests such as aphids (Fig. 3). However, their positioning closer to the origin and being far away from the particular diseases or pests shows they were tolerant to the diseases or pests.

These correspondence ordination with symmetrical scaling for association of pests, diseases and varieties results were also supported by those from hierarchical clustering (Fig. 3). Generally, the genetic distances between varieties were small which can be owed to low genetic diversity in the set of varieties used in this study. Moreover, there were no specific clusters for pests and diseases of reaction for landraces or improved varieties but rather a mixture of both landraces and improved varieties (Fig. 2 and 
Fig. 3). In relation to reaction of groundnut accessions to aphids and Rosette virus disease, three clusters (I, II \& III) could be identified as resistant, tolerant and susceptible, respectively (Fig. 3).

\section{Evaluation of growth and yield performance of groundnuts at the two study sites}

Results of combined analysis for growth and yield over two growing locations are presented in Table 4 and Fig. 4. Significant $(P<0.05 P<0.001)$ MS for drought tolerance and germination but non-significant $(P>0.05) M S$ for yield and growth were observed for variation due to class of genotype. Significant $(P<$ 0.05 to $P<0.001) M S$ due to variation in the locations (sites) were observed for all traits. The interactions MS between class and site were also significant $(P<0.05$ to $P<0.001)$ for all the traits.

Table 4

Significance of mean squares for growth and yield performance for different class groundnut accessions grown at different sites.

\begin{tabular}{|c|c|c|c|c|c|c|c|c|c|}
\hline $\begin{array}{l}\text { Source of } \\
\text { variation }\end{array}$ & Df & Germination & & Growth & & $\begin{array}{l}\text { Drought } \\
\text { tolerance }\end{array}$ & & Yield & \\
\hline Site & 1 & 307756 & $\star \star \star$ & $\begin{array}{l}1.15 E+ \\
06^{*}\end{array}$ & & $1.87 E+06$ & * & $\begin{array}{l}1.45 \mathrm{E} \\
+15\end{array}$ & 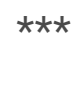 \\
\hline Class & 1 & 3999.55 & $\star \star \star$ & 316.179 & & 2306.5 & $\star \star \star$ & $\begin{array}{l}2.70 \mathrm{E} \\
+12\end{array}$ & \\
\hline Interaction & 1 & 2579.87 & $\star \star \star *$ & 18111.7 & $\star \star \star *$ & 32006.2 & $\star \star \star *$ & $\begin{array}{l}1.18 \mathrm{E} \\
+14\end{array}$ & * \\
\hline Within & 3275 & 298.28 & & & & & & & \\
\hline Total & 3278 & & & & & & & & \\
\hline
\end{tabular}

Graphical representation of mean yield performance of improved and landraces at different growing sites is presented in Fig. 4. The interaction between site and mean genotypic performance for traits can be described as qualitative (crossover) for the case of yield and quantitative (non-crossover) for other traits (growth, drought tolerance and germination (Fig. 4).

\section{Discussion}

\section{Comparison of yield performance of selected improved groundnut varieties and landraces}

Genetic variability of traits plays an important role in plant survival, adaptability, and can be utilised to predict the genetic gain from selection in breeding programmes. A wide range in values of yield was observed for the groundnut accessions tested in this study which confirms the existence of genetic variability for the yield traits (Upadhyaya et al. 2005; Nigram and Aruna 2008; Songsri et al. 2008; 2009, 2013). However, yield was higher in landraces compared to improved varieties. This may be explained by higher greenness index (persistence and concentration of chlorophyll in leaves) observed in landraces compared to improved varieties. A higher greenness index is associated with the ability of the crop to accumulate high biomass which is also correlated to pod yield under both stress and non-stress 
conditions (Koolachart et al. 2013). This observation agrees with findings of Oppong-Sekyere et al. (2019) and Kakeeto et al. (2020).

\section{Comparison of germination performance of selected improved and landraces}

A higher germination of seeds depends on availability of favourable environmental factors like adequate temperature, light, salinity, moisture, water (Cokkizgin 2012) and presence of seed borne pathogens (Ahmed et al. 2017). In this study, landraces performed better than improved varieties when judged in terms of germination. The difference in germination between these classes of groundnut could be related to adaptability of these lines to growing environments. This observation is supported by that of Salasya et al. (2007). Moreover, farmers are known to regenerate their seeds on a regular basis since they cannot afford other seed preservation methods. However, what cannot be explained by these results though is the known fact that seed in farmers' hands tend to accumulate seed borne diseases (Frost et al. 2013; Gergerich et al. 2015; Thomas-Sharma et al. 2016) which should reduce their vigour at germination and growth period.

\section{Comparison of growth parameters of selected improved varieties and landraces}

Growth form in groundnuts differs depending on the subspecies and botanical variety (Krapovikas and Gregory 1994). Groundnut accessions used in this study differed in their growth abilities with landraces being relatively taller than improved varieties. The difference in plant height between these classes can be attributed the sub species maintained or managed in the country's gene pool. Most of the improved varieties used in this study belong to sub species hypogaea (virginia market types) and these are normally runners or small bush types while most of the landraces were predominantly well adapted sub species fastigiata (valencia market types) which are normally erect with potential to grow taller depending on the growing environment, including competition subjected to them by weeds or other crops in mixed cropping systems. Growth progression measured as plant height among landraces ranged from 25 to $59.4 \mathrm{~cm}$ while that in the modern varieties ranged from 25 to $52.1 \mathrm{~cm}$. Literature pertaining to differences in plant growth of landraces versus improved varieties is not well documented. However, results from studies by Kakeeto (2018) found that plant height of groundnut materials tested in Uganda varied from 15.3 to 54.6 depending on season and the botanical variety of the groundnut accession. Moreover, Salasya et al. (2007) reported that improved groundnut varieties took longer days to emerge and flower due to poor adaptation to the environment, but the landrace grew better because they were well-adapted to the environment.

\section{Comparison of drought tolerance level of selected improved groundnut varieties and landraces}

Stay green is an important trait that allows plants to retain their leaves in an active photosynthetic state when exposed to stress conditions (Thomas and Howarth 2000). Stay-greenness has been used as a criterion for selecting stay-green genotypes in various crops (Christopher et al. 2014; Lope and Reynolds 2012; Trachsel et al. 2016; Borrell et al. 2014). We report significant variation in the stay green trait among landraces and improved varieties with the former maintaining greenness for a longer time compared to 
latter. This is in contradiction to the findings by Oppong-Sekyere et al. (2019) who found improved varieties to have higher chlorophyll concentration than landraces over well-watered and water-stressed conditions.

Reaction of selected improved groundnut varieties and landraces to natural pest and disease infestations

Another important selection criterion used by groundnut producers is the pests and disease reaction (Okello et al. 2010, 2014, Mugisa et al. 2015, Kakeeto et al. 2018). The reaction of groundnut varieties to pests and diseases didn't significantly differ between landraces and improved varieties, even though incidence of pests and diseases was lower on improved varieties. These results corroborate those of Kakeeto et al. (2018) where farmers selected improved varieties over landraces for their pest and disease resistance. However, these results contradict those of Aina et al. (2011) who reported that landraces had better tolerance to CMD and CBB diseases compared to improved varieties of cassava. Results from similarity clustering showed that clustering was not based on groupings as landrace or improved variety but rather a combination of both improved and landraces. Moreover, these combinations had unique associations with particular pests and diseases. These results imply that choice of a resistant groundnut variety shouldn't be informed by their grouping as landraces or improved varieties, but on associations identified between individual varieties and pest/diseases that have to be considered when making selections for breeding pipe lines or target production environments (high disease pressure vs low disease pressure) growing areas.

Effect of significant GE interaction on performance of selected improved groundnut varieties and landraces

Genotype environment interaction exists whenever the relative phenotypic performance of genotypes varies with the environment. Significant G x E interactions were observed in all characters studied for both landraces and improved varieties. Several research groups have also reported similar results (Mothilal et al. 2010; Songsri et al. 2008; Minde et al. 2017; Aina et al. 2011). In this study, both crossover and non-cross over GE were observed.

Significance of GE has serious implications for deployment of varieties (Kang 1993). While non-crossover GE can be exploited by improving the growing environment, the crossover GE calls for selection and deployment of specifically adapted varieties. Cross- over GE was only observed for yield implying that high performers from both improved and landraces could be specifically deployed in the respective sites. On the other hand, non-cross over GE could be overcome by modifying the production sites. Related to this recommendation, biophysical description of the two sites indicates that although Nakaseke site has better conditions for crop growth, Nakasongola has the largest share of locations suitable for groundnut production; which also confirms the inherent drought tolerant nature of this crop (Erickson and Ketring 1985; Reddy et al. 2003). Therefore, strategies such as irrigation, use of conservation agriculture, and adoption of drought tolerant varieties could boost performance of both improved varieties and landraces in Nakasongola. 


\section{Conclusion}

The current study aimed to explore the presence of genetic and geographic structures in a collection of groundnuts representing the existing variability for this species in the Ugandan gene pool. There were no clear structures for either landraces or improved varieties with respect to the traits investigated. The differences or similarities observed could largely be explained by the genetic pools managed by the breeding programmes operating in the country and those in the hands of farmers coupled with differences in the target growing environments. The results reported in the current study may be used to facilitate development of new cultivars building on inherent strengths of both well adapted landraces and improved varieties with desirable traits thus the need to conserve these varieties for sustainable use.

\section{Declarations}

Conflicts of Interest/competing interests

The authors declare no conflicts of interest. The sponsors had no role in the design of the study; in the collection, analyses, or interpretation of data; in the writing of the manuscript, and in the decision to publish the results.

Data Availability of data and materials

Data used to support these findings can be sourced from the corresponding author. The datasets generated during and/or analysed during the current study are available from the corresponding author on reasonable request.

Code Availability

The analysis code can be accessed from corresponding author

Authors' Contribution: NA

Ethics approval: NA

Consent to participate: NA

Consent for publication: NA

Acknowledgments

We thank the site teams and the farmers of the Nakaseke and Nakasongola sites for their participation in the research on which the paper is based.

\section{References}


1. Adamu AS, Salaudeen MT, Gana AS, Ishaq MN (2015) Response of selected soybean (Glycine max [L.] Merr.) lines to Cucumber mosaic virus disease in Minna, Niger State. Nig J Agric Food Environ 11(4):45-51

2. Ahmed O, Olayika BU, Garuba T, Ahmed J, Etejere EO (2017) Germination of several groundnut cultivars in relation to incidence of fungi. Science World Journal 12(1):38-41

3. Aina OO, Dixon AGO, llona P, Akinrinde EA (2009) Gx E interaction effects on yield and yield components of cassava (landraces and improved) genotypes in the savanna regions of Nigeria. Africa Journal of Biotechnology Vol 8(19):4933-4945

4. Araú́jo PM, Nass LL (2002) Caracterização e avaliação de populações de milho crioulo. Science in Agriculture 59:589-593

5. Borrell AK, van Oosterom EJ, Mullet JE et al (2014) Stay-green alleles individually enhance grain yield in sorghum under drought by modifying canopy development and water uptake patterns. New Phytol 203(3):817-830

6. Christopher JT, Veyradier M, Borrell AK, Harvey G, Fletcher S, Chenu K (2014) Phenotyping novel staygreen traits to capture genetic variation in senescence dynamics. Funct Plant Biol 41(11):1035-1048

7. Cokkizgin A (2012) Salinity Stress in Common Bean (Phaseolus vulgaris L.). Seed Germination Not Bot Horti Agrobo 40(1):177-182

8. David AM, Haverkampb BJ, Laurenzc RG, Orlowskid JM, Wilsone EW, Casteelf SN, Leeg CD et al (2016) Characterizing genotype $\times$ management interactions on soybean seed yield. Crop Sci 56(2):786-796

9. Eberhart SA, Russell WA (1966) Stability parameters for comparing varieties. Crop Sci 6:36-40

10. Erickson P, Ketring D (1985) Evaluation of peanut genotypes for resistance to water stress in situ. Crop Sci 25:870-876

11. FAO (1996) Global Plan of Action for the Conservation and Sustainable Utilization of Plant Genetic Resources and the Leipzig Declaration, adopted by the International Technical Conference on Plant Genetic Resources, Leipzig, Germany, 17-23 June 1996. Food and Agriculture Organization of the United Nations, Rome, Italy

12. Finlay KW, Wilkinson GN (1963) Analysis of adaptation in a plant breeding programme. Aust J Agric Res 14:742-754

13. Frost KE, Groves RL, Charkowski AO (2013) Integrated control of potato pathogens through seed potato certification and provision of clean seed potatoes. Plant Dis 97:1268-1280

14. Futakuchi K, Tobita S, Diatta S, Audebert A (2003) WARDA's work on the New Rice for Africa (NERICA)-interspecific Oryza sativa L. x O. glaberrima Steud. progenies. Jpn. J. Crop Sci. 72(Extra issue 1): 324-325

15. Gauch HG Jr (1988) Model selection and validation for yield trials with interaction. Biometrics 44:705-715 
16. Gergerich RC, Welliver RA, Gettys S, Osterbauer NK, Kamenidou S, Martin RR, Golino DA, Eastwell K, Fuchs M, Vidalakis G, Tzanetakis IE (2015) Safeguarding fruit crops in the age of agricultural globalization. Plant Dis 99:176-187

17. Griffiths AJF, Miller JH, Suzuki DT, Lewontin RC, Gelbart WM (1996) An Introduction to Genetic Analysis. WH Freeman and Company, New York

18. Joshi AK, Kumari M, Singh VP et al (2007) "Stay green trait: variation, inheritance and its association with spot blotch resistance in spring wheat (Triticum aestivum L.)," Euphytica, vol. 153, no. 1-2, pp. 59-71, 2007

19. Kakeeto R (2018) Development of Drought Tolerant Groundnut (Arachis hypogaea L.) Genotypes with Better Agronomic and Seed Physical Quality Traits in Uganda. PhD Thesis., University of KwaZulu Natal

20. Kakeeto R, Melis R, Biruma $M$ et al (2020) Gene action governing the inheritance of drought tolerance and selected agronomic traits in Ugandan groundnut (Arachis hypogaea L.) lines under drought environment. Euphytica 216:1. https://doi.org/10.1007/s10681-019-2539-6

21. Kakeeto R, Sibiya J, Melis R, Biruma M (2018) Farmers' perceptions of drought, and other production constraints, drought mitigation options, and their implications for groundnut breeding in Uganda. Indian journal of Agricultural Research 53(1):45-50

22. Kang MS (1993) Simultaneous selection for yield and stability in crop performance trials: Consequences for growers. Agron J 85:754-757

23. Kashiwagi J, Krishnamurthy L, Upadhyaya HD, Krishna H, Chandra S, Vedez V, Serraj R (2005) Genetic variability of drought-avoidance root traits in the mini-core germplasm collection of chickpeas (Cicer arietinum L.). Euphytica 146(3):213-222

24. Koolachart R, Suriharn B, Jogloy S, Vorasoot N, Wongkaew S, Holbrook C, Jongrungklang C, Kesmala NT, Patanothai T A (2013) Relationships between physiological traits and yield components of peanut genotypes with different levels of terminal drought resistance. SABRAO Journal of Breeding Genetics 45:422-446

25. Krapovickas A, Gregory WC (1994) Taxonomia del genero Arachis (Leguminosae). Bonplandia 8:1186

26. Ledingham RJ, Atkinson TJ, Horricks JS, Mills JT, Pienning LJ, Tinline RJ (1973) Wheat losses due to common root rot in Prairie Provinces of Canada, 1969-71. Can. Plant Dis Sur 53:113-122

27. Malosetti M, Ribaut J, van Eeuwijk FA (2013) The statistical analysis of multi-environment data: modeling genotype-by-environment interaction and its genetic basis (2013) Front. Physiol., https://doi.org/10.3389/fphys.2013.00044

28. Minde AS, Kamble MS, Pawar RM (2017) Stability analysis for pod yield and its component traits in groundnut (Arachis hypogaea L.). Asian Journal of Biological Sciences 12(1):15-20

29. Morris M, Mekuria M, Gerpacio R (2003) Impacts of CIMMYT maize breeding research. In: Evenson RE, Gullin D (eds) Crop variety improvement and its effect on productivity. The impact of international agricultural research, Chap. 7. CABI, Wallingford, pp 135-158 
30. Mothilal A, Vindhiyavarman P, Manivannan N (2010) Stability analysis of foliar disease resistant groundnut genotypes (Arachis hypogaea L.). Electronic Journal of Plant Breeding 1:1021-1023

31. Mugisa IO, Karungi J, Akello B, Ochwo-Ssemakula MKN, Biruma M, Okello DK, Otim G (2015) Assessing the effect of farmers' practices on the severity of groundnut rosette virus disease in Uganda. Afr J Agric Res 10(9):995-1003

32. Mugisha J, Lwasa S, Mausch K (2014) Value chain analysis and mapping for groundnuts in Uganda, Socio-economics discussion paper series number 14

33. Mukankusi C, Kyamanywa S, Adipala E (2000) Leaf miner (Aproarema modicella Deventer): A new pest in Uganda. IPM

34. Nigam SN, Aruna R (2008) Stability of soil plant analytical development (SPAD) chlorophyll meter reading (SCMR) and specific leaf area (SLA) and their association across varying soil moisture stress conditions in groundnut (Arachis hypogaea L.). Euphytica 160:111-117

35. Nigam SN, Prasada R, Bhatnagar-Mathur P, Sharma KK (2012) Genetic management of virus diseases in peanut. Plant Breeding Reviews 36:293-356

36. Nimusiima A, Basalilwa CPK et al (2013) African Journal of Environmental Science and Technology. Vol. 7(8), pp. 770-782, August 2013 DOI: 10.5897/AJEST2013.1435

37. Ogwang BA, Chen H, Li X, Gao C (2016) Evaluation of the capability of RegCM4.0 in simulating East African climate. Theor Appl Climatol 124:303-313

38. Okello DK, Biruma M, Deom CM (2010) Overview of groundnuts research in Uganda; Past, Present and future. Afr J Biotech 9:6448-6459

39. Okello DK, Okori P, Puppala N, Ureta BB, Deom CM, Ininda J, Anguria P, Biruma M, Asekenye C (2014) Groundnuts seed production manual for Uganda. National Agricultural Research Organisation, Entebbe. ISBN: 978-9970-401-12-3 15

40. Oppong-Sekyere D, Yintii BB, Akolgo LA (2019) Assessment of Selected Landrace and Improved Groundnut (Arachis hypogaea L.) Genotypes under Stressed and Non-stressed Conditions. Journal of Experimental Agriculture International 40(1):1-25. https://doi.org/10.9734/jeai/2019/v40i130355

41. Øyvind H, Harper DAT, Ryan PD (2001) Past: Paleontological Statistics Software Package for Education and Data Analysis. Palaeontologia Electronica, vol. 4, issue 1, art. 4: 9pp., 178kb. http://palaeo-electronica.org/2001_1/past/issue1_01.htm

42. Pasupuleti J, Nigam SN (2013) Phenotyping for groundnut (Arachis hypogaea L.) improvement. In: Panguluri. SK, Kumar AA (eds) Phenotyping for plant breeding. Springer, New York, pp 129-167

43. Paterniani E, Nass LL, Santos MX, Valor dos Recursos $O$ (2000) Genéticos de Milhopara o Brasil: Uma AbordagemHistórica da Utilizaçãodo Germoplasma. In: Udry CW, Duarte W (eds) Uma História Brasileirado Milho: $O$ Valor dos Recursos Genéticos. Paralelo, Brasília, pp 11-14

44. Reddy T, Reddy V, Anbumozhi V (2003) Physiological responses of groundnut (Arachis hypogea L.) to drought stress and its amelioration: a critical review. Plant Growth Regul 41:75-88 
45. Salasya BW, Mwangi D. Mwabu, Diallo A (2007) Factors Influencing. Adoption of stress tolerant maize hybrid (WH 502) in Western Kenya. Africa Journal of Agricultural Research 2(10):544-551

46. Savage GP, Keenan JL (1994) The composition and nutritive value of groundnut kernels. In: Smart J (ed) The Groundnut crop: Scientific basis for improvement. Chapman and Hall, London, Pages 173 21

47. Sharma SB, Jain KC, Lingaraju S (2000) Tolerance of reniform nematode (Rotylenchulus reniformis) race $A$ in pigeonpea (cajanus cajan) genotypes. Annu Appl Biol 136(3):247-252

48. Singh M, Yau SK, Hamblin J, Porceddu E (1996b) Inter-site transferability of crop varieties: another approach for analyzing multi-locational variety trials. Euphytica 89:305-311

49. Songsri P, Jogloy S, Holbrook CC, Kesmala T, Vorasoot N, Akkasaeng C, Patanothai A (2009) Association of root, specific leaf area and SPAD chlorophyll meter reading to water use efficiency of peanut under different available soil water. Agric Water Manag 96:790-798

50. Songsri P, Jogloy S, Junjittakarn J, Kesmala T, Vorasoot N, Holbrook CC, Patanothai A (2013) Association of stomatal conductance and root distribution with water use efficiency of peanut under different soil water regimes. Aust J Crop Sci 7:948-955

51. Songsri P, Jogloy S, Kesmala T, Vorasoot N, Akkasaeng C, Patanothai A (2008) Heritability of drought resistance traits and correlation of drought resistance and agronomic traits in peanut. Crop Sci 48:2245-2253

52. Songsri P, Joygloy S, Kesmala T, Vorasoot N, Akkasaeng C, Patanothai A (2008) Heritability of drought resistance traits and correlation of drought resistance and agronomic traits in peanut. Crop Sci 48:2245-2253

53. Subrahmanyam $P$, McDonald D, Waliyar F et al., "Screening methods and sources of resistance to rust and late leaf spot of groundnut," 1995, http://oar.icrisat.org/3477/

54. Thomas H, Howarth CJ (2000) "Five ways to stay green," Journal of Experimental Botany, vol. 51, no. 1, pp. 329-337, 2000

55. Thomas-Sharma S, Abdurahman A, Ali S, Andrade-Piedra J, Bao S, Charkowski A, Crook D, Kadian M, Kromann P, Struik P, Torrance L, Garrett KA, Forbes GA (2016) Seed degeneration in potato: the need for an integrated seed health strategy to mitigate the problem in developing countries. Plant Pathol 65:3-16

56. Trachsel S, Sun D, SanVicente FM et al (2016) "Identification of QTL for early vigor and stay-green conferring tolerance to drought in two connected advanced backcross populations in tropical maize (Zea mays L.)," PLoS One, vol. 11, no. 3, Article ID e0149636

57. Trachsel S, Sun D, SanVicente FM et al (2016) "Identification of QTL for early vigor and stay-green conferring tolerance to drought in two connected advanced backcross populations in tropical maize (Zea mays L.)," PLoS One, vol. 11, no. 3, Article ID e0149636

58. Upadhyaya HD (2005) Variability for drought resistance related traits in the mini core collection of peanuts. Crop Sci 45:1432-1440 
59. Van Der Plank JE (1965) Dynamics of epidemics of plant disease. International Journal of Pest Management: Part B 11(3):307-317

60. Villa TCC, Maxted N, Scholten M, Ford-Lloyd B (2005) Defining and identifying crop landraces. Plant Genet Resour 3, 373-384. doi: 10.1079/ PGR200591

61. Waliyar $F$ (1991) Evaluation of yield losses due to groundnut leaf diseases in West Africa. Summary proceedings of the second ICRISAT regional groundnut meeting for west Africa, 11-14 Sep 1990, ICRISAT Sahelian Centre, Niamey, Niger. Patancheru 502 324, Andhra Pradesh, India: ICRISAT, pp 3233

62. Wood AJ, Roper J (2000) A Simple and Nondestructive Technique for Measuring Plant Growth and Development. American Biology Teacher v62:n3 p215-17

63. Xu W, Rosenow DT, Nguyen HT (2000) Stay green trait in grain sorghum: relationship between visual rating and leaf chlorophyll concentration. Plant Breeding 119(4):365-367

64. Yates F, Cochran WG (1938) The analysis of groups of experiments. J Agric Sci 28:556-580

65. Zeven AC (1998) Landraces: A review of definitions and classifications. Euphytica 104:127-139

\section{Figures}

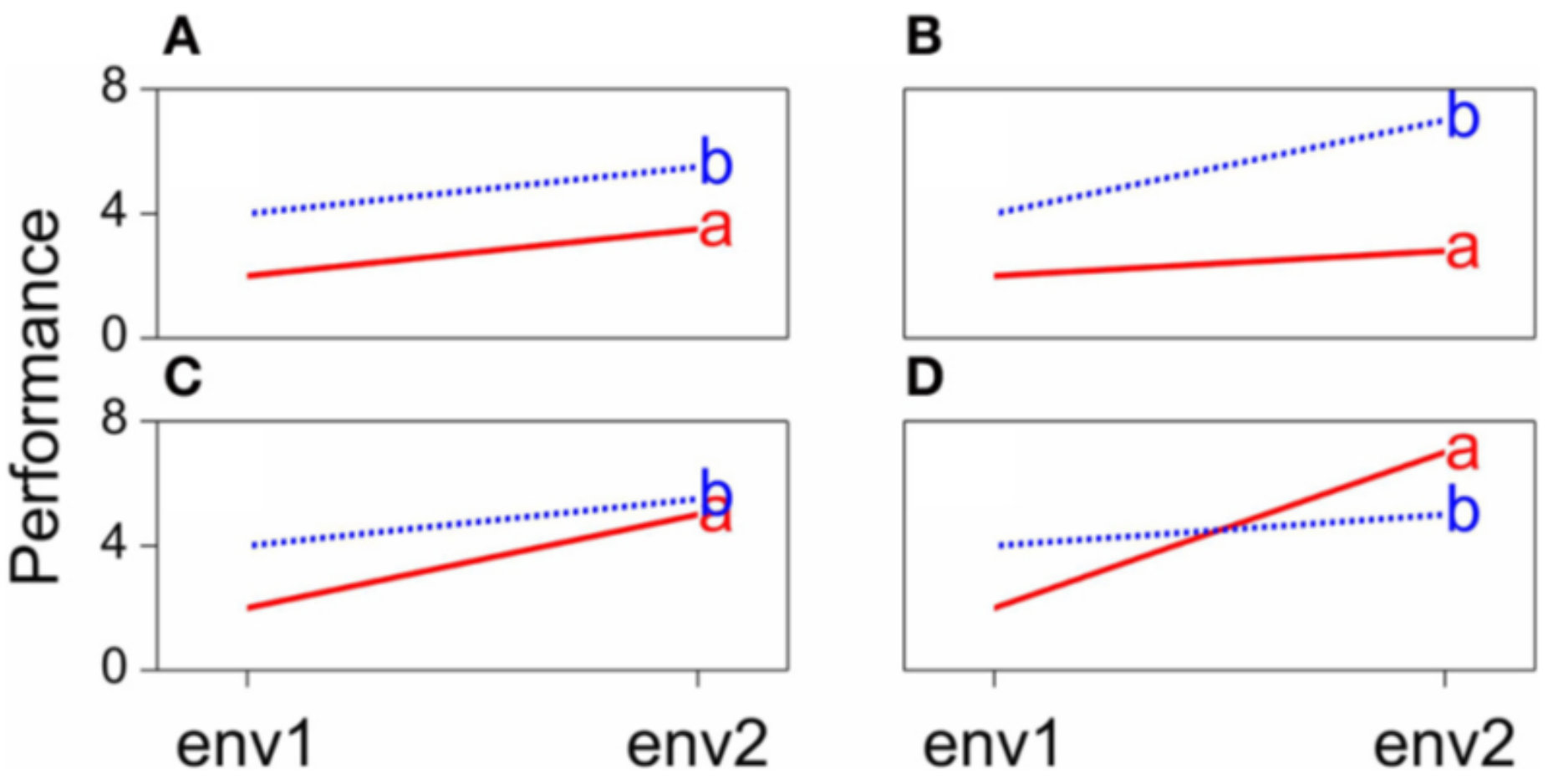

Figure 1

Genotype-by-environment interaction in terms of changing mean performances across environments: (A) additive model, (B) divergence, (C) convergence, (D) cross-over interaction (Source: Malosetti et al. 2013) 

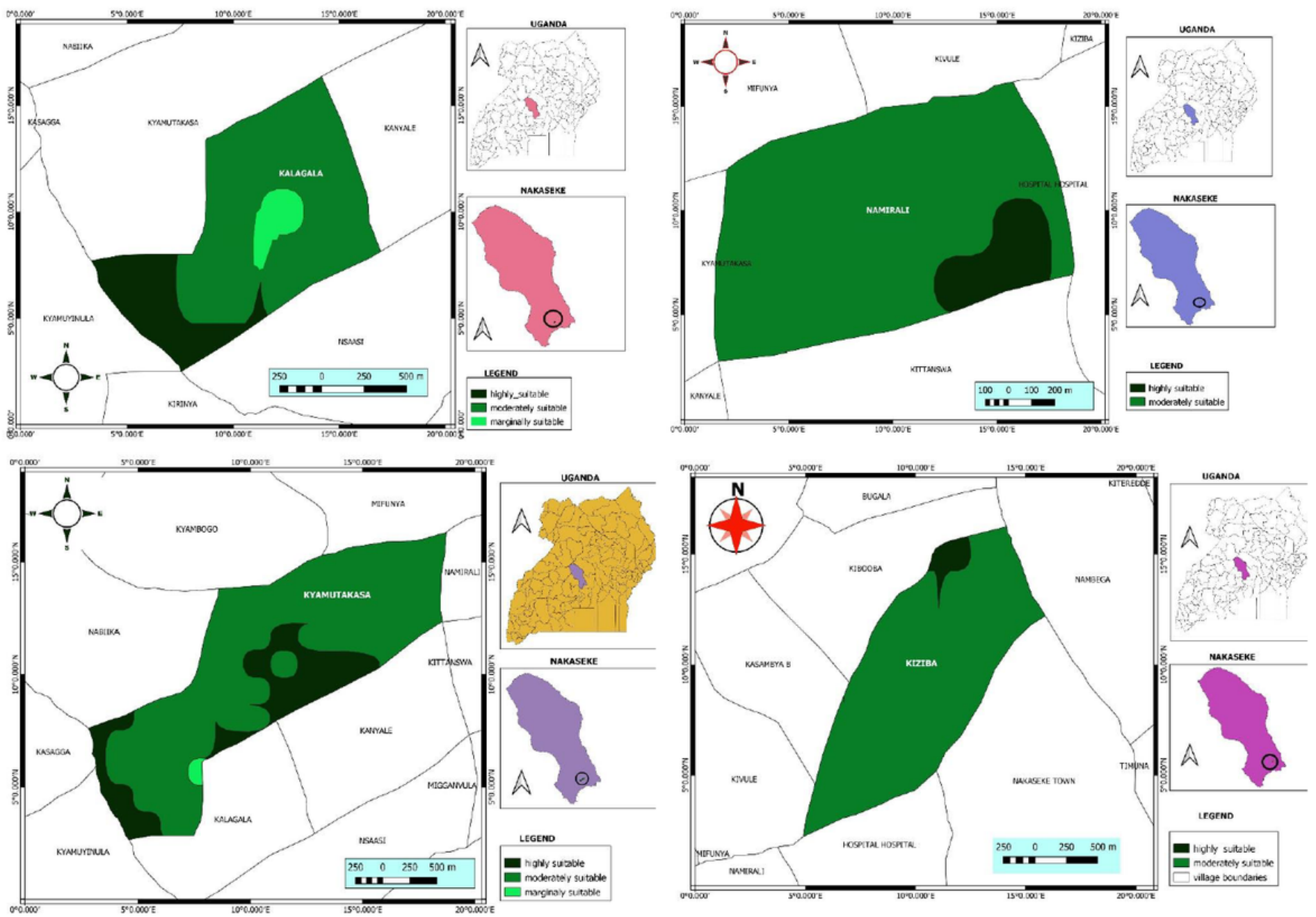

Figure 2

Map of trial locations (villages) within Nakaseke District 

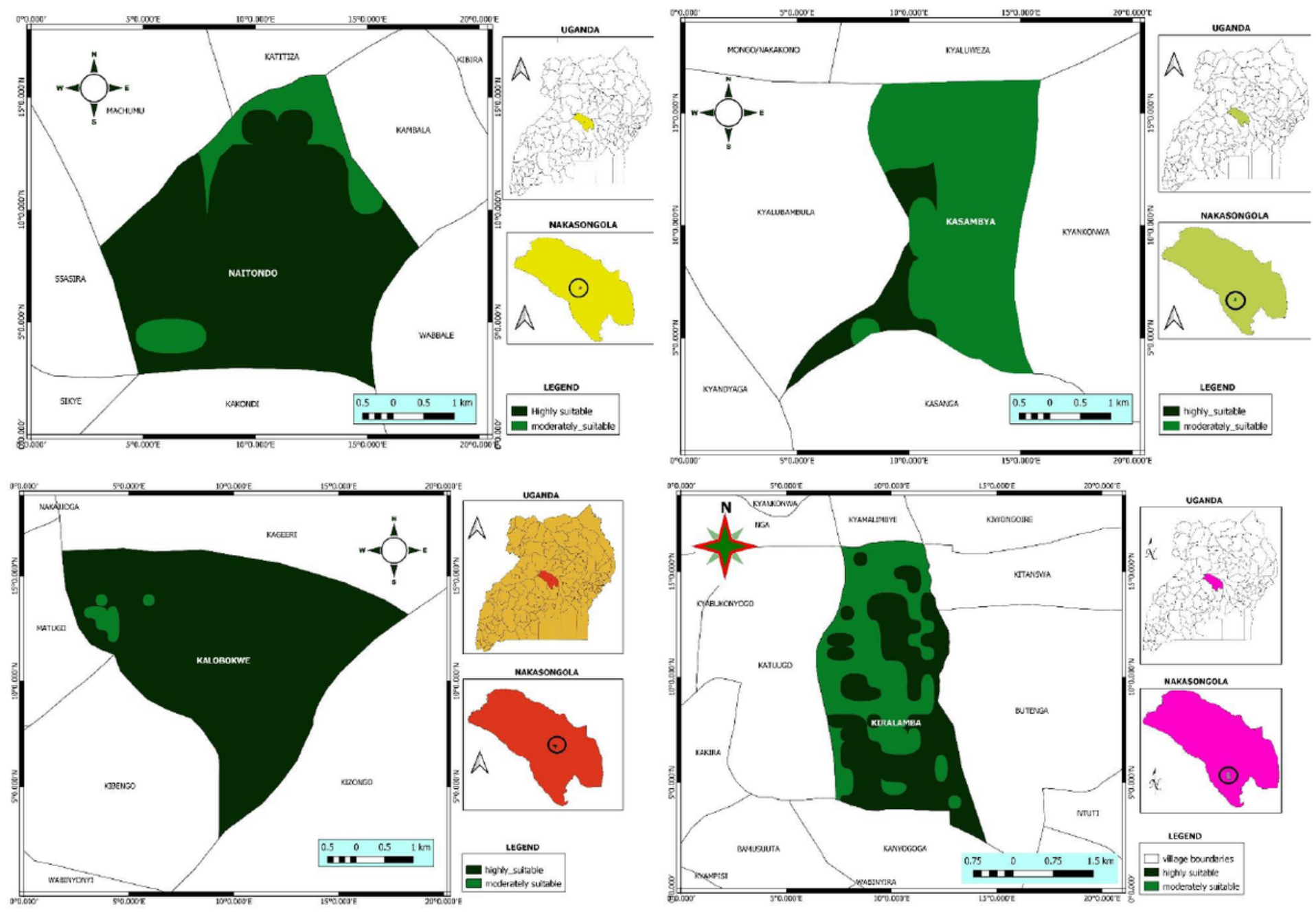

Figure 3

Map of trial locations (villages) within Nakasongola District

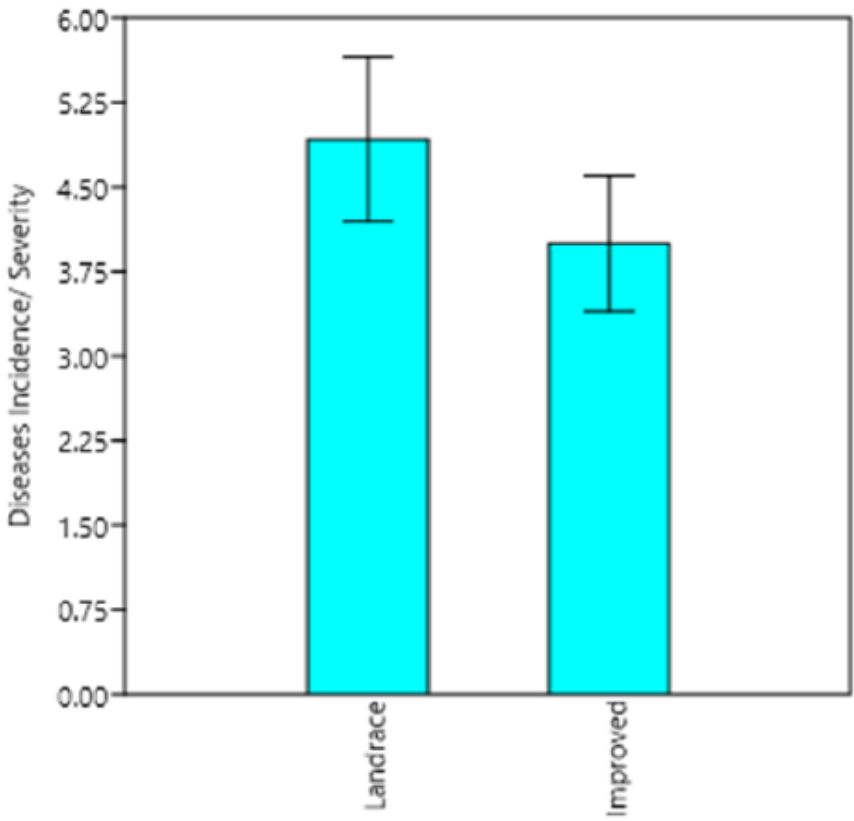

Mann-Whitn $\mathrm{U}=52 ; \mathrm{P}($ same med $=0.67)$

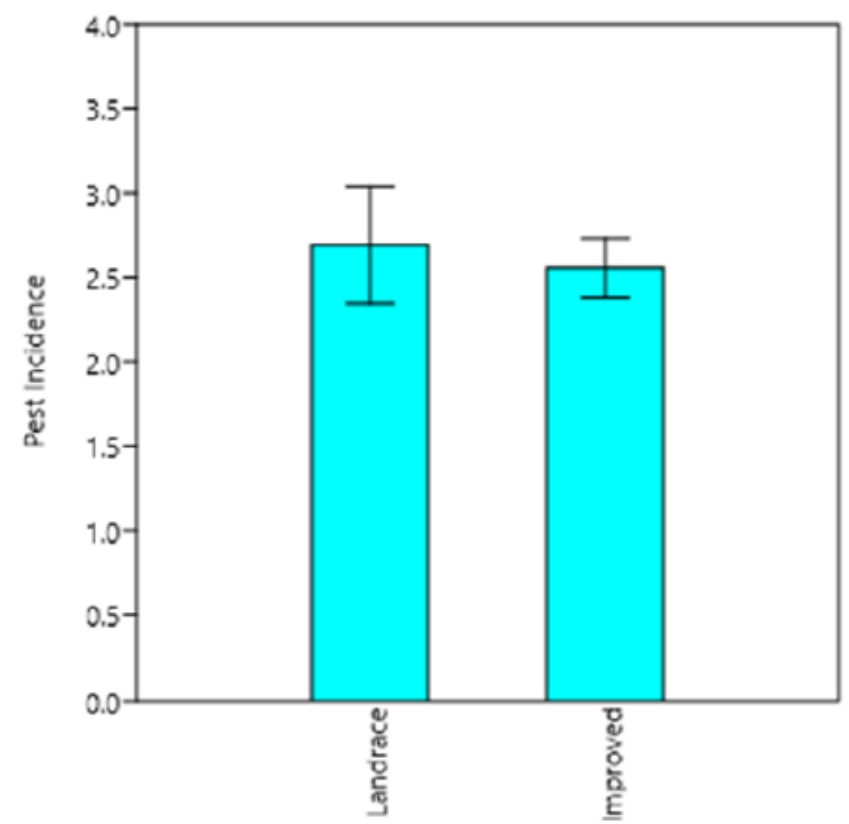

Mann-Whitn $\mathrm{U}=58.5 ; \mathrm{P}($ same med $=0.97)$ 
Figure 4

Box plots showing reaction of landraces and improved groundnuts to diseases and pests

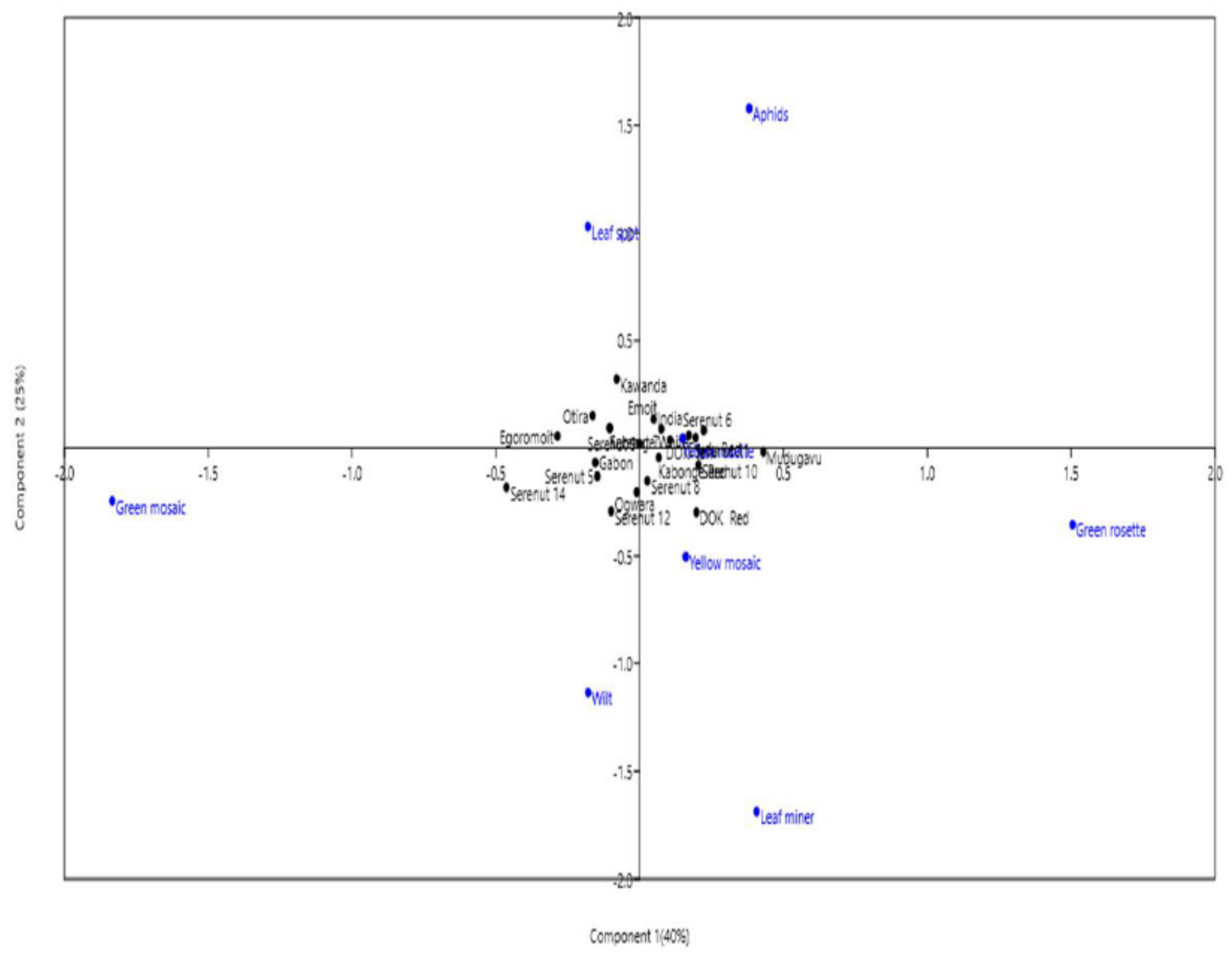

Figure 5

Correspondence ordination with symmetrical scaling for association of pests, diseases and varieties 


\section{Distance}
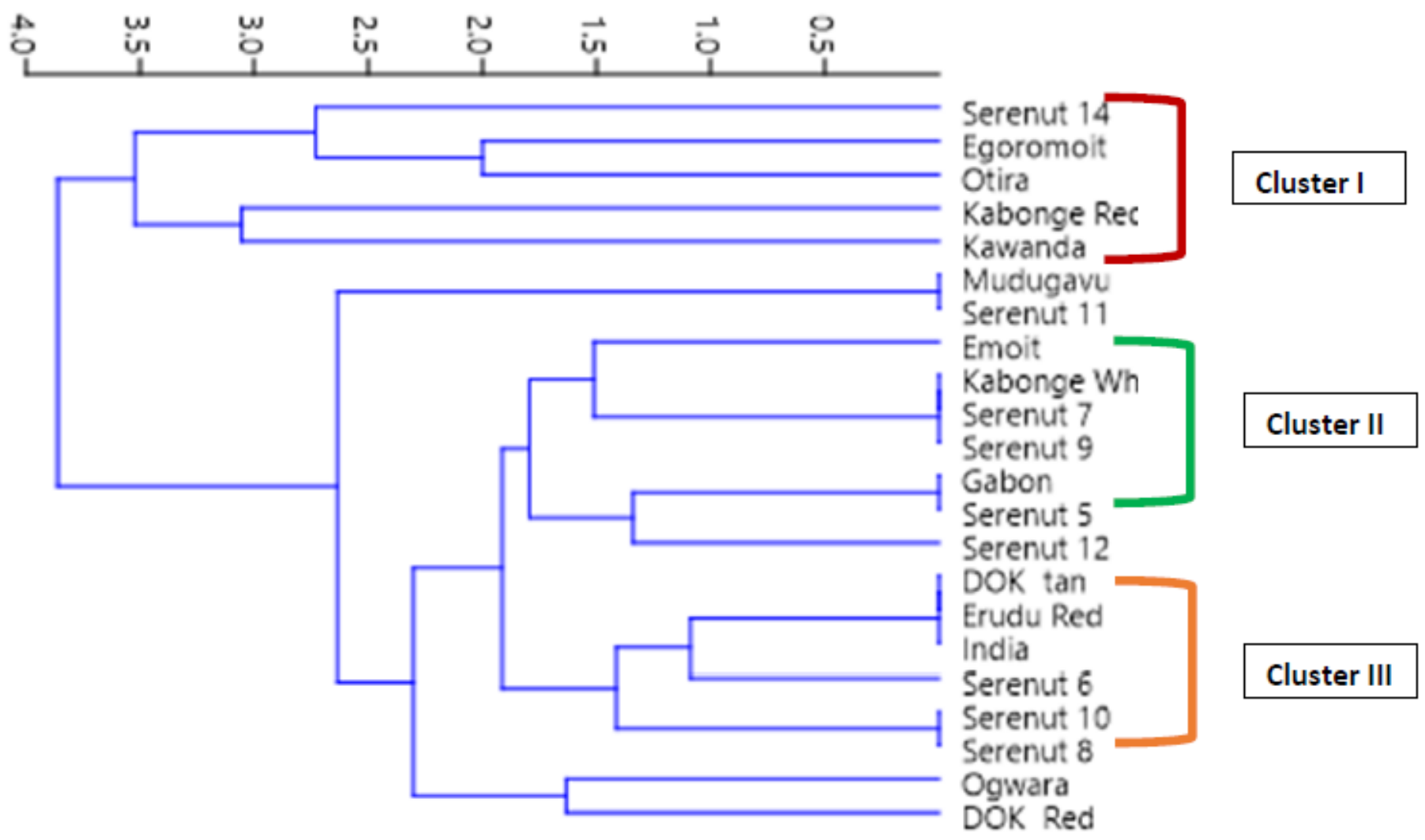

Figure 6

Hierarchical clustering using distance matrices showing similarities between varieties in relation to aphids and Rosette virus disease reaction 


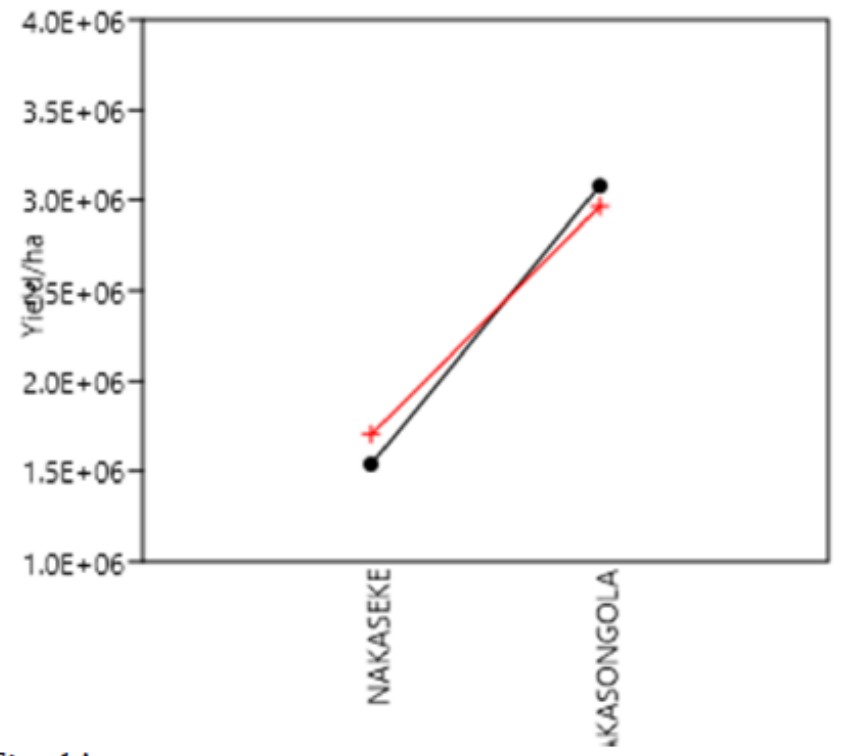

Fig. 4A

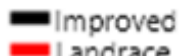

- Landrace

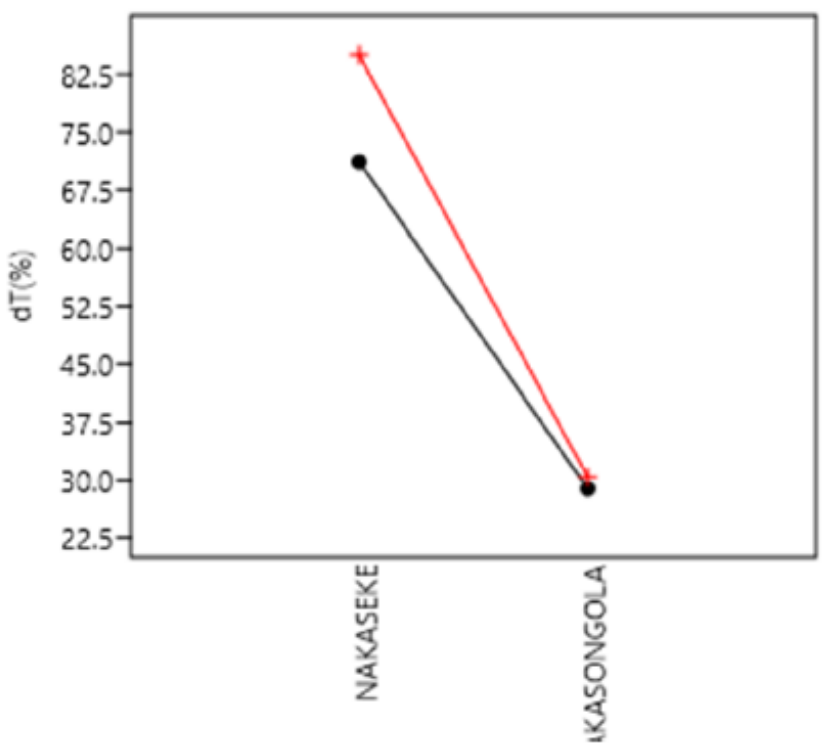

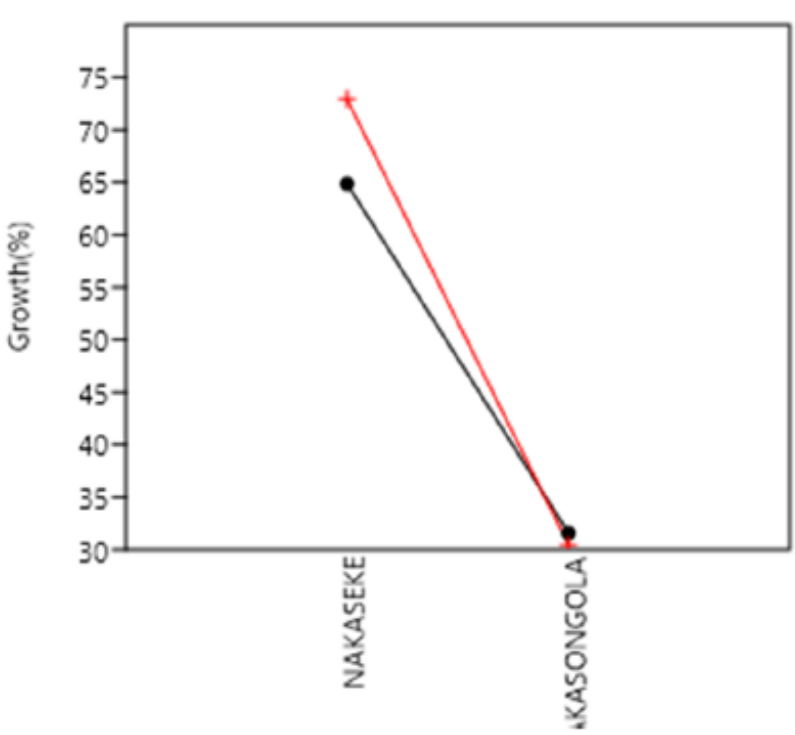

Fig.4B
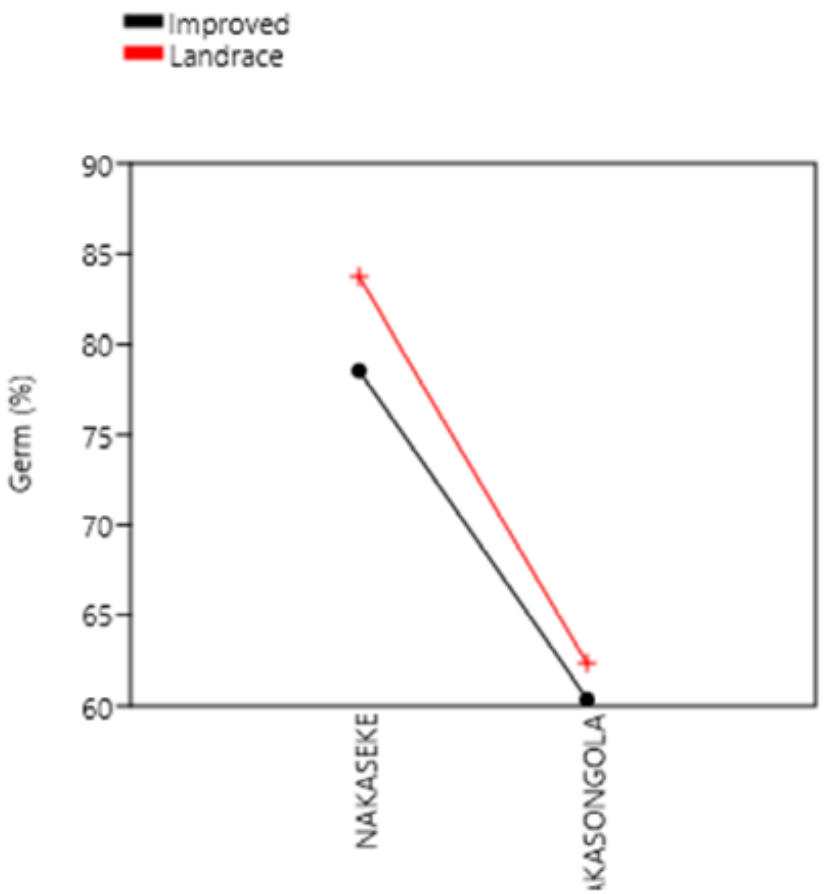

Figure 7

Genotype-by-environment interaction in terms of changing mean performances across environments: (A) Yield, (B) Growth, (C) Drought tolerance, (D) Germination 